\title{
$13: 21143875-21174187$
}

National Cancer Institute

\section{Source}

National Cancer Institute. 13: 21143875-21174187. NCI Thesaurus. Code C42268.

Physical location of FGF9_Gene 